DOI https://doi.org/10.30525/978-9934-26-004-9-93

\title{
ВПЛИВ МУЗИЧНОГО МИСТЕЦТВА НА РОЗВИТОК ЗДІБНОСТЕЙ ДІТЕЙ В УМОВАХ ІНКЛЮЗИВНОЇ ОСВІТИ
}

\author{
Ткемаладзе 3. П. \\ викладач-методист кафедри \\ музично-інструментальної підготовки вчителя
}

Золотарьова О. I.

старший викладач, викладач-методист кафедри

музично-інструментальної підготовки вчителя

Комунального закладу «Харківська гуманітарно-педагогічна академія»

Харківської обласної ради

м. Харків, Україна

Реформа системи освіти висуває розвиток творчості дитини, як одне із пріоритетних завдань. Без ії вирішення неможливо виконати головні завдання освіти в Україні - формування базиса особистої культури дитини через відкриття їі світогляду у цілому і різнобічному.

Дитина не повинна пасивно спостерігати оточуючий світ, вживати готову їнформацію і копіювати іiі. Саме від творчих людей залежить розвиток суспільства. Перші творчі здібності особистості проявляються в дошкільному віці. Перед вихователем стоїть завдання знайти шляхи своєчасного прояву у кожної дитини інтересів, природних задатків, здібностей і створити оптимальні умови для їх розвитку. I визначати конкретні сфери творчого потенціалу.

Як відомо, музика - вид мистецтва, який суттєво впливає на становлення особистості. Вона збагачує почуття дитини, сприяє оволодінням вмінням відчувати ритм і мелодію твору, формує здібності адекватно реагувати на них своїм голосом і рухами, розвиває інтерес до різних музичних інструментів і бажання на них грати. Головне в музичному розвитку повести дитину в різнобарвний світ музики, навчити дитину жити нею. Завдання педагога полягає в тому, щоб дитина робила це не тому, що так треба, а щоб дитина сказала: «Я буду робити це тому, що хочу, тому, що це мені цікаво» [2, с. 4].

Допомогти дитині відчути красоту і силу впливу музики-це важливе i важке завдання. Музичне виховання- частина естетичного виховання дитини. Естетичне виховання проходить через ознайомлення дітей 3 94 
різними видами мистецтва (музика, образотворче мистецтво, театр, хореографія, література, фольклор). Музика розвиває музичну культуру і формує позитивні якості особистості. Музика в більшій ступені, ніж інші види мистецтва доступна дитині.

Про те, як впливає музика на розвиток дитини написано чимало посібників, наукових трактатів. У людини яка має музичну освіту, або багатий досвід використання в своєму житті музики немає сумніву в тому, що музика розвиває і виховує в дитині моральні, душевні, розумові та вольові якості. Однак сьогодні у багатьох батьків виникає запитання: чи варто навчати дитину музиці? У них не виникає сумніву коли йде мова про навчання математики, географії i iнших предметів, передбачених шкільною програмою. У батьків постає питання-чи варто витрачати сили і час дитини, якщо вона надалі не буде спеціалістом в музичній галузі? Що дасть музика дитині для реального життя, для пізнання? Що може дати дитині музика?

Можна довго сперечатись з цього питання, але існують такі факти. Дослідники з університету Вісконсена виявили, що кожна дитина, яка народжується має досить тонкий музичний слух і чуття ритму. Але ці здібності можуть згаснути за кілька років якщо їх не розвивати. [1, с.127]

На думку дослідників саме завдяки музичному слуху та чуттю ритму дитина сприймає розмову людей. Усього за кілька місяців малюк накопичуе в пам'яті тисячі слів, як ритмічно-звуковисотні так i інтонаційно організовані звукові фрагменти. 3 розвитком відчуття ритму в малюка якісно змінюються складові його психіки, необхідні для різних видів діяльності, поведінки в цілому.

За допомогою комп'ютерних технологій дослідники 3'ясували, що музика впливає на розвиток мозку і моторики людини, сприяє розвитку аналітичного мислення. В експерименті брало участь 78 дошкільнят, яких розділили на 3 групи. Дітей 1 групи навчали музичної грамоти та гри на фортепіано, 2-роботи на комп'ютері, в Зй групі ніяких спеціальних занять не проводили. Через пів року було проведено тестування розумових здібностей дітей в усіх 3ох групах. Виявилося, що діти, які вивчали музичне мистецтво, показали результати на $34 \%$ вищі, ніж їх однолітки з других груп. На підставі даних цього експерименту дослідники дійшли висновку, що музика сприяє розвиткові аналітичного мислення, i чим дитина раніше починає займатись музикою, тим кращим буде результат.

Музичні вподобання можуть чимало сказати про внутрішній світ людини, іiі душевний стан. Щоб дитина розвивалася музично, не обов'язково чекати ї вступу до музичної школи. Прилучати малюка до 
музики може людина і без музичної освіти. Якомога більше співайте 3 дітьми дитячі пісеньки,репертуар дуже багатий. Добре, якщо діти будуть мати можливість слухати музику різних жанрів: класичну музику, народну,просту i складну, симфонічну, запис звучання сучасних та народних музичних інструментів. Добре використовувати різні види сприймання музики на слух. Тобто: пасивне(коли дитина чує звучання але зайнята іншим); частково активне-дитина слухає але водночас думає про своє(музика в цьому разі є для нього джерелом емоційного стану натхнення); і нарешті активне сприймання,коли дитина намагається виконувати ту чи іншу пісеньку, співає уривки з неї, помічає коли співають неправильно. Активне сприймання слід розвивати, ніякий інструмент не замінить дитині переживання безпосередньої участі в творенні музичних звуків за допомогою власного голосу, власних відчуттів.

Що дуже є важливим -ніколи не слід казати дитині, що вона співає погано, що в неї немає слуху(навіть коли це так). Правильність відтворення музичних звуків тісно пов'язана 3 вірою в себе. Можна сказати, що вона співає майже правильно, але звук треба спочатку прослуховувати, а потім співати. Багато в чому властивості голосу визначаються анатомічними особливостями, будовою гортані, об'ємом навколоносових пазух. Вокальні м'язи у дошкільнят ще не розвинуті. Дитячий спів не можна оцінювати за критерієм сили звучання. Гучний спів та крик шкодять незміцнілим м'язам дітей, притуплюють слух та негативно позначаються на нервовій системі

Спів відіграє важливу роль не лише в музичному, а і в загальному розвитку дитини. Проспівування слів та фраз на одному диханні покращує дитячу вимову, зміцнює легені, активізує обмінні процеси. Вокалізовані вправи та ігри використовують не лише музкерівники а й логопеди і терапевти.

Дітям із слабкими мовними данними добре допомагають вправи на поєднання співу 3 пасивними рухами, співуче читання, ритмічне читання-чергування коротких і довгих складів за рухом руки, поєднання мовної інтонації з музикою тощо.

Обдарованість $є$ найвищим проявом здібностей дитини. Тому серед групи здібних дітей лише одна може бути обдарованою. Музична обдарованість проявляється в дуже ранньому віці, тому наше завдання полягає в своєчасному виявленні цих здібностей у дітей. Найбільше, звичайно, нас цікавлять музичні здібності дітей. Таких дітей, виявити не важко.

Наприклад, діти, в яких є музичні здібності: 
- люблять музику і музичні записи, намагаються бути там, де звучить музика;

- швидко і легко відгукуються на ритм, мелодію, уважно прислуховуються до них, легко запам'ятовують;

- діти які співають, або швидко освоюють гру на музичних інструментах, вивчені твори вони виконують 3 почуттям, 3 настроєм;

- діти які вміють створювати свої мелодії, і на музичних заняттях, під час імпровізації простих мелодій, вони легко справляються 3 цим завданням.

Чим раніше ми почнемо розвивати у дітей ці здібності, тим більше шансів їх повністю розкрити. На жаль, популярний вислів «талант себе виявить» не відповідає дійсності. Нерідко трапляється так, що діти приховують свої здібності, якщо ми не оцінюємо їх належним чином. Обдарована дитина сама собі допоможе, якщо ми підтримаємо іiі творчість. Тому музичні заняття повинні бути завжди творчими, цікавими, результативними. А, оскільки, творчі здібності проявляються найбільше у грі, то ми постійно використо- вуємо елементи гри на музичних заняттях. Велику роль у розвитку творчих здібностей дітей відіграють вечори розваг, свята, музично-театралізовані дійства, де діти, в повній мірі, можуть розкрити свої співочі, танцювальні та акторські здібності. Також ми окремо плануємо роботу з дітьми, в яких є ознаки обдарованості. I, звичайно ж, дуже важлива в роботі з обдарованими дітьми співпраця музичного керівника, вихователів і батьків.

Таким чином хочеться сказати, що не слід ділити дітей на «математиків», «співаків», «танцюристів», «читців», «розумних» і не дуже, бо ці характеристики дуже несталі і тимчасові. Все залежить від розвивальної роботи, яка проводиться з дитиною. I не будемо забувати, що для ефективної реалізації здібностей треба створити, насамперед, сприятливі умови в сім’ї і в усіх ланках освіти.

\section{Література:}

1. Зязун І.А., Крамущенко Л.В., Кривонос І.Ф. Педагогічна майстерність. 3-е вид. К.: СПД Богданова А.М., 2008. 376 с.

2. Міжнародний інноваційний центр гармонійного розвитку людини/ Під редакцією Н. Мельник. К.: Піснезнайка, 2003.

3. Недериця С. Музична терапія як засіб лікувального та розвивального впливу на дітей. Музичний керівник, 2011. № 5. - С. 4-5. 